\title{
Corporate Governance Mechanisms: Evidence From Small- and Medium-Sized Enterprises (SMEs)
}

\author{
Angeline Kiew-Heong Yap \\ HELP University, Kuala Lumpur, Malaysia \\ Yan-Ling Ng \\ Universiti Tunku Abdul Rahman, Selangor, Malaysia
}

This paper aims to investigate the extent to which Malaysian small- and medium-sized enterprises (SMEs) adopted corporate governance (CG) principles and their effects on firm performance. The principles examined included: establishing clear roles and responsibilities; strengthening composition; and reinforcing independence. The paper is based on a questionnaire survey study among 113 SMEs that consisted of 35\% (39) of manufacturing and related services and 65\% (74) from services including information and communication technology (ICT), primary agriculture, construction, mining, and quarrying. The analysis of the data indicates that $32 \%$ of the respondents said that the primary reason why they have their own business is to have control over their own working life. This finding appears to confirm the financing theory that SMEs owners have other goals than profitability. In addition, 30\% of SMEs perceived that the most important role played by the board is risk management; hence, these boards have a greater control over financial risks that may lead to better financial performance. The analysis also shows that $81 \%$ of the respondents' board consisted of internal board members only. These enterprises need to see the important role of external board members as a source of advice providers and experts to them. For policies relating to clear roles and responsibilities of board, only $28 \%$ of the respondents established clear functions reserved for the board and those delegated to management; substantial respondents did not draw up policies relating to reinforce board independency (between $75 \%$ and $79 \%$ ) and to strengthen board composition (46\%). Besides, $68 \%$ of the respondents have the position of chairman and CEO held by same individuals and $81 \%$ of the chairman is an executive member of the board. These findings suggest that SMEs cannot see the importance of strengthening board and having independent board members. Regression analysis also indicates that board independence has a significant and positive impact on firm performance. Hence, SMEs need to appreciate networking advantages, competency, and strategic knowledge that the right board can offer. The governmental ministries and agencies in Malaysia need to take active measures to encourage SMEs to strengthen their board governance, because SMEs are the important economic powers for stimulating national economic growth. This paper contributes to the empirical literatures on the adoption of CG principles and their effects on SMEs' firm performance in emerging markets.

Keywords: corporate governance (CG), small- and medium-sized enterprises (SMEs), emerging markets, Malaysia

\footnotetext{
Angeline Kiew-Heong Yap, senior lecturer, Faculty of Business, Economics, and Accounting, HELP University. Email: angeline.yap@help.edu.my.

Yan-Ling Ng, lecturer, Faculty of Accountancy and Management, Universiti Tunku Abdul Rahman.
} 


\section{Introduction}

Corporate governance (CG) is a whole set of rules taken by social entities or enterprises to produce favourable economic performance, to generate organisational surplus, and to distribute the wealth created among society stakeholders. The Malaysian Code on Corporate Governance (MCCG, 2012, p. 9) defined CG as:

The process and structure used to direct and manage the business and affairs of the company towards enhancing business prosperity and corporate accountability with the ultimate objective of realising long-term shareholder value, whilst taking into account the interests of other stakeholders.

The new announcement for the new definition of a small- and medium-sized enterprise (SME) was made on the beginning of the year 2014 by the Prime Minister of Malaysia. These changes have been made due to the transformation of business structure and trend from year 2005 till now. The basic definition of an SME was still by looking at their annual sales turnover and their full-time employees. The annual sales turnover for manufacturing-related services ranges from not exceeding RM50 million or full-time employees not exceeding 200, whereas for the service sector, sales turnover should not exceed RM20 million or full-time employees should not exceed 75 (SME Corporation Malaysia, 2013). The qualification criterion for a company to be listed under SME Malaysia is to meet either one of the annual sales turnover or by the full-time employees. An original SME company needs to concern that if its business annual sales turnover or its full-time employee's number has exceeded this basic qualification criterion for two financial years, then the business is no longer being listed under SME Malaysia. The same goes to originally large companies; if they continuously meet the qualification criterion for also two financial years, then they will be listed as SME Malaysia.

The rapid growth of SMEs in Malaysia provides a need for the type of CG which fits SMEs as it represents a large tissue of the Malaysian economy. According to SME Latest Annual Report 2012/2013, Malaysia's SMEs constituted $97.3 \%$ of total business in 2011. In addition, GDP growth of 6\% is contributed by SMEs in 2012. By 2020, SMEs should contribute 65\% of Malaysia GDP. Therefore, examining the board composition and the compliance of governance codes for SMEs is crucial from the context of a developing economy like Malaysia. Jensen (1993) argued that effective governance system is applicable to SMEs to ensure long-term performance and to be socially responsible institutions. An effective governance system provides favorable advantages to owners and managers, enhancing transparency and disclosure of information and increasing the sustainability of the firm when crisis hits (Htay \& Salman, 2013). In addition, to have an effective governance system, other appraisals from stakeholder perspectives, such as trading relationship with suppliers and customers, market shares growth, and employment opportunity, are to be included by SMEs (Abor \& Adjasi, 2007).

Most of the CG codes and empirical studies focus on public listed companies. Eisenberg, Sundgren, and Wells (1998), Bennett and Robson (2004), and Abor and Adjasi (2007) stated that there are limited studies in governance issues for SMEs. Hence, the objective of this paper is to bridge this research gap on the adoption of CG principles and their effects on SMEs' performance in Malaysia. The rest of the paper is organized as follows: Section 2 presents the governance literatures of SMEs; Section 3 outlines the methodology; results are discussed in Section 4; and conclusions are drawn in Section 5.

\section{Literature Review}

From the CG theory perspective, board is seen as an important CG mechanism to influence governance and firm's performance. Agency theory has been developed to resolve the conflict between owners and 
managers of larger firms that have a separation between both parties. This theory is less relevant to SMEs, because most of the SMEs are made up of only the owner who is also the manager and few employees who are mostly relatives of the owner. Hence, agency problems are less likely to exist (Abor \& Adjasi, 2007). However, there is a need for boards to act as monitoring organs because of a close family connection between owners and family-related employees. According to Neville (2011), other agency problems, such as diverging interests and conflicts, may arise between owners, because they may not always be motivated by financial rewards (Neville \& Nykredit, 2010). Studies found that owners felt that it was more important to control daily management operations than to pursue business growth (Neville \& Nykredit, 2010; Neville, 2011).

Storey (1994) argued that most small firms are characterized with a lack of internal expertise and resources. Therefore, these small firms need right competencies of owners and managers. Neville and Nykredit (2010) discovered that board of directors in SMEs bore several responsibilities and hence a combined multi-theory way to expand these distinct roles is needed. From the resource-based theory perspective, the board is seen to add value-creation and competitive advantages to the firm with their knowledge and skills (Neville, 2011). In addition, an external board is able to link SMEs to external firms through their networking to attract resources that add value-creation to the firm (Neville, 2011).

Stewardship theory sees managers as stewards of the firm; their motives are aligned with the owner's interest; and there is no conflict between the separation of ownership and control (Arosa, Iturralde, \& Maseda, 2010). The main responsibility of the board is to serve, advise, and contribute by bringing different experiences and competencies to help managers in decision-making process. Therefore, they can facilitate strategic change process for SMEs (Neville, 2011).

The case study of Htay and Salman (2013) shows that Malaysian SMEs recognize the importance of CG system to ensure transparency, accountability, and disclosing relevant financial information for enterprises' value creation. Jasani (2002) reported that founders controlled 59\% of SMEs in Malaysia whilst 30\% were run by the founders' children. This indicates that a paradigm shift towards generation plays an important direction in the firm's development. Family businesses should implement an effective succession process to develop their heirs for long-term business sustainability.

Most SMEs' boards consist of owners and relatives with very few independent board members. Therefore, it is very important for SMEs to have an active board which consists of independent board members (Brunninge \& Nordqvist, 2004). Outside director board members are not involved in daily operations; they provide strategic options with their own experiences from other perspectives to provide new ideas (Brunninge, Nordqvist, \& Wiklund, 2007). The outside directors have different styles of interpretation and gaining information will have a wider scope of the markets, operations, and competitors, thus helping SMEs to make a strategic decision-making and creating opportunities for improvement (Georgiou, 2010; Latini, 2011). Arosa et al. (2010) argued that outside directors produce a positive effect on firm performance in family firms run by the first generation.

As discussed above, there is growing acknowledgement that the board of directors plays a significant role in improving the economic efficiency and growth of SMEs. To be competitive in this changing world, SMEs must be willing to adopt good governance principles to meet challenging demands of all stakeholders and to grasp business opportunities available. In view of this important role of good governance principles to SMEs, the researchers examine the board composition and governance structure of SMEs. This study contributes to the empirical literatures on the adoption of CG principles and their effects on SMEs' firm performance in emerging markets. 


\section{Methodology}

This study is based on a questionnaire survey among 116 owner-managed SMEs. This study included all forms of firms and all trade sectors defined as SMEs under the Guideline for New SME Definition issued by SME Corporation Malaysia Secretariat (October 2013). A team of 49 research assistants who are final-year accounting undergraduates assisted the researchers to collect the data. Each questionnaire was mailed to the respondents together with a cover letter stating the research objectives and specifying that the anonymity of the respondents is completely preserved. The questionnaire consists of two parts. Part A comprised questions relating to roles and responsibilities of board, board composition, and their independence. These questions were developed based on MCCG (2012) and past literatures (Abor \& Adjasi, 2007; Neville, 2011). Part B asked about the respondents' demographics profile. Table 1 shows the profile of the respondents.

\section{Results}

\section{Descriptive Statistics}

Table 1 showed that $65 \%$ of the respondents were from services and other sectors, of which $42 \%$ employed between five and less than 30 employees. In terms of the annual sales, $30 \%$ of the respondents generated between RM300,000 and less than RM3,000,000 sales annually.

Table 1

Profile of the Respondents

\begin{tabular}{|c|c|c|}
\hline Respondents' profile & No. of respondents $(N)$ & $\%$ \\
\hline \multicolumn{3}{|c|}{ Manufacturing and manufacturing-related services } \\
\hline \multicolumn{3}{|l|}{ Number of full-time employees } \\
\hline$<5$ & 6 & 5 \\
\hline 5 to $<75$ & 21 & 19 \\
\hline 75 to $<200$ & 12 & 11 \\
\hline Total & 39 & 35 \\
\hline \multicolumn{3}{|l|}{ Annual sales turnover } \\
\hline$<\mathrm{RM} 300,000$ & 5 & 4 \\
\hline RM300,000 to $<$ RM15,000,000 & 22 & 20 \\
\hline RM15,000,000 to $<$ RM50,000,000 & 12 & 11 \\
\hline Total & 39 & 35 \\
\hline \multicolumn{3}{|c|}{$\begin{array}{l}\text { Services and other sectors (including information and } \\
\text { communication technology (ICT), primary agriculture, } \\
\text { construction, mining and quarrying) }\end{array}$} \\
\hline \multicolumn{3}{|l|}{ Number of full-time employees } \\
\hline$<5$ & 13 & 11 \\
\hline 5 to $<30$ & 48 & 42 \\
\hline 30 to $<75$ & 13 & 12 \\
\hline Total & 74 & 65 \\
\hline \multicolumn{3}{|l|}{ Annual sales turnover } \\
\hline$<$ RM300,000 & 14 & 12 \\
\hline RM300,000 to $<\mathrm{RM} 3,000,000$ & 34 & 30 \\
\hline $\mathrm{RM} 3,000,000$ to $<\mathrm{RM} 20,000,000$ & 26 & 23 \\
\hline \multirow[t]{2}{*}{ Total } & 74 & 65 \\
\hline & 113 & \\
\hline
\end{tabular}


Neville (2011) argued that owners perceived that they will bear greater risk if management was to take care of their business. In addition, organizational efficiency can only be achieved when the owners are in control of the business, because ownership and control go together. Table 2 confirmed this argument, since $32 \%$ of the respondents said that the primary reason why they have their own business is to have control over their own working life. This finding is consistent with the results reported by Neville and Nykredit (2008) and Neville (2011), which argued that financial reward is not the main goal pursued by SMEs owners.

Table 2

What Are the Primary Reasons Why You Have Your Own Business?

\begin{tabular}{lcc}
\hline Reason & $\begin{array}{l}\text { No. of } \\
\text { respondents }(N)\end{array}$ \\
\hline To have control over my own working life & 65 & 32 \\
To work in a field that interests me & 41 & 20 \\
To be able to realize my own ideas & 40 & 19 \\
To get a high salary and/or ongoing financial dividends & 34 & 17 \\
To obtain financial gains in the long term when selling the business & 26 & 12 \\
Total & 206 & 100 \\
\hline
\end{tabular}

Table 3 showed that $30 \%$ of the respondents perceived the most important role of the board to be risk management, because a board has a higher degree of control over an enterprise's strategy for risk management (Neville, 2011). McKinsey \& Company (2009) argued that enterprises that implemented risk management strategies and procedures helped to improve economic performance.

Table 3

The Most Important Role of the Board

\begin{tabular}{|c|c|c|}
\hline Role of the board & $\begin{array}{l}\text { No. of } \\
\text { respondents }(N)\end{array}$ & $\%$ \\
\hline To monitor the business and its management, including the risks that can threaten the business & 86 & 30 \\
\hline To lay down the strategy of the business & 56 & 20 \\
\hline To help bring new customers to the business & 31 & 11 \\
\hline Do not know & 30 & 10 \\
\hline To contribute competences to the business which it would not otherwise have & 19 & 7 \\
\hline To foster good relations with the external business partners, such as banks & 19 & 7 \\
\hline To ensure that the business complies with legal requirements & 18 & 6 \\
\hline To ensure that ensuring conflicts do not arise between the owners & 16 & 5 \\
\hline To ensure that the business's financial resources benefit all the owners & 11 & 4 \\
\hline Total & 286 & 100 \\
\hline
\end{tabular}

As can be seen from Table 4, only 15\% of SMEs have boards with outside members. This small percentage may be due to that SMEs have few employees who are mostly related to owner and SMEs do not face public accountability issues because most SMEs are sole proprietorship businesses. Hence, SMEs' owner may be reluctant to share control with outside board members. Other reasons for not appointing outside members may include costly, creating additional work, and bureaucracy; and afraid to lose the ability to respond quickly to business opportunity (Neville, 2011). However, outside members are important sources of knowledge, skills, and experience, and they help to increase the awareness range of management issues (Johannisson \& Huse, 2000) and facilitate the strategic change process of SMEs (Voordeckers, Van Gils, \& Van den Heuvel, 2007; Brunninge et al., 2007). 
Table 4

Board Composition of the Company

\begin{tabular}{lcr}
\hline Board composition & No. of \\
respondents $(N)$ & $\%$ \\
\hline Company with internal board & 92 & 81 \\
Company with boards with outside members & 17 & 15 \\
Do not know & 4 & 4 \\
Total & 113 & 100 \\
\hline
\end{tabular}

Table 5 revealed that Malaysian SMEs placed a great emphasis on establishing clear functions reserved for board and management (28\%), followed by ensuring that the company's strategies promote sustainability (24\%). According to MCCG (2012), establishing clear functions helps to understand and ensure accountability of both parties. Regular review is required to ensure that the enterprise's needs are consistently met. The responsibility of both parties should reflect the dynamic nature of the enterprise to adapt to ever changing external environments. In order to promote strategy sustainability, SMEs need to pay attention to social and environmental aspects of the business.

Table 5

Which of the Following Policies Relating to the Clear Roles and Responsibilities of the Board Has Your Company Drawn Up (MCCG Principle 1)?

\begin{tabular}{lcc}
\hline Policy related to the clear roles and responsibilities of the board & $\begin{array}{l}\text { No. of } \\
\text { respondents }(N)\end{array}$ & $\%$ \\
\hline Establish clear functions reserved for the board and those delegated to management & 64 & 28 \\
Ensure that the company's strategies promote sustainability & 54 & 24 \\
Establish clear roles and responsibilities in discharging its fiduciary and leadership functions & 36 & 16 \\
Formalize ethical standards through a code of conduct and ensure its compliance & 28 & 12 \\
Ensure that it is supported by a suitably qualified and competent company secretary & 15 & 7 \\
Have procedures to allow its members to access information and advice & 11 & 6 \\
None of the above & 7 & 2 \\
Formalize and periodically review its board charter/group & 229 & 100 \\
Total & & 5 \\
\hline
\end{tabular}

As can be seen from Table 6, 46\% of the respondents did not draw up policies related to strengthening board composition. Some argued that SMEs do not need to practise CG, because the majority of their employees are related family members. The agency problem and disagreement do not arise, because related employees are rewarded directly. Since they do not depend on public fund, the question of accountability also does not arise (Abor \& Adjasi, 2007). Even though, the separation of ownership and management is less pronounced in SMEs, they should be aware of the importance of strengthening board composition for effective monitoring, advising, and servicing roles (Htay \& Salman, 2013), in view of the rapid growth and complex nature of the businesses.

Tables 7 and 8 revealed that SMEs did not place a great emphasis on board independence. As seen in Table 7, 75\% of the respondents did not undertake an assessment of independent directors annually and their boards did not comprise a majority of independent directors. This could be due to that SMEs owners are reluctant to share control with independent directors (Brunninge \& Nordqvist, 2004); having independent directors may be costly in time and money; and SMEs owners are fearful of being thought ignorant by independent directors (Thomas, Coleman, \& Howieson, 2007). 
Table 6

Which of the Following Policies Related to Strengthening Composition of the Board Has Your Company Drawn Up (MCCG Principle 2)?

\begin{tabular}{lcc}
\hline Policy related to strengthening board composition & $\begin{array}{l}\text { No. of } \\
\text { respondents }(N)\end{array}$ & $\%$ \\
\hline $\begin{array}{l}\text { None of the below } \\
\text { Develop, maintain, and review the criteria to be used in the recruitment process and annual } \\
\text { assessment of directors }\end{array}$ & 31 & 46 \\
$\begin{array}{l}\text { Establish formal and transparent remuneration policies and procedures to attract and retain } \\
\text { directors }\end{array}$ & 32 & 4 \\
$\begin{array}{l}\text { Establish a nominating committee which should comprise exclusively non-executive } \\
\text { directors, the majority of whom must be independent }\end{array}$ & 5 & 100 \\
Total & 126 & 4 \\
\hline
\end{tabular}

Table 7

Which of the Following Policies Related to Reinforcement of Board Independence Has Your Company Drawn Up (MCCG Principle 3)?

\begin{tabular}{lcc}
\hline Policy related to reinforcement of board independence & $\begin{array}{l}\text { No. of } \\
\text { respondents }(N)\end{array}$ & $\%$ \\
\hline None of the below & 88 & 75 \\
Undertake an assessment of its independent directors annually & 18 & 15 \\
Comprise the majority (> 50\%) of independent directors & 11 & 10 \\
Total & 117 & 100 \\
\hline
\end{tabular}

According to Table 8, 68\% of the respondents have the positions of chairman and CEO held by the same individuals, and $81 \%$ of their chairman is an executive board member. Jensen (1993) argued that to have effective governance systems, a firm should include CEO who is the only insider on the board and the CEO is seldom the chairman of the board. The findings suggest that SMEs owners do not use the board as a value internal resource (Neville, 2011). The SMEs do not appreciate networking advantages and strategic knowledge that the right board can offer. This will result in lower standards of governance and may adversely affect their competitiveness, potential growth, and innovation (Neville, 2011; Abor \& Adjasis, 2007).

Table 8

Reinforcement of Board Independence (MCCG Principle 3)

\begin{tabular}{|c|c|c|c|c|}
\hline Board independence & Yes $(\%)$ & No $(\%)$ & $\begin{array}{l}\text { Do not } \\
\text { know }(\%)\end{array}$ & Total (\%) \\
\hline $\begin{array}{l}\text { Does your company have the tenure of an independent director exceeded a } \\
\text { cumulative term of nine years? }\end{array}$ & 16 & 76 & 8 & 100 \\
\hline $\begin{array}{l}\text { Upon completion of nine years, does your company re-designate an independent } \\
\text { director as a non-independent director through shareholders' approval? }\end{array}$ & & 79 & 9 & 100 \\
\hline Are the positions of chairman and CEO held by different individuals? & 29 & 68 & 3 & 100 \\
\hline Is the chairman a non-executive member of the board? & 19 & 81 & 0 & 100 \\
\hline
\end{tabular}

\section{Regression Analysis}

To test the effect of MCCG (2012) "Principle 1: Establish Clear Roles and Responsibilities”, "Principle 2: Strengthen Composition", and "Principle 3: Reinforce Independence" on sales performance, the following multiple regression was run:

$$
Y=\beta_{0}+\beta_{1} X_{1}+\beta_{2} X_{2}+\beta_{3} X_{3}+\varepsilon
$$


where $Y=$ Sales; $X_{1}=$ MCCG (2012) Principle 1; $X_{2}=$ MCCG (2012) Principle 2; $X_{3}=$ MCCG (2012) Principle 3; $\varepsilon=$ Error term; $\beta_{0}=$ The intercept; and $\beta_{1}, \beta_{2}$, and $\beta_{3}=$ The regression coefficients for the three MCCG (2012) principles.

The results presented in Table 9 show that the coefficient $\beta_{2}$ (strengthen composition) is negatively significantly related to sales performance, while $\beta_{3}$ (reinforce independence) is positively significantly associated with sales performance. The whole model is significant $(F=6.700 ; p=0.000)$ and explains $15.2 \%$ of the sales performance variance.

Table 9

CG Principles and Sales Performance

\begin{tabular}{llll}
\hline Variable & Beta & $t$-value & Sig. \\
\hline Constant & -1.358 & -1.509 & 0.134 \\
\hline MCCG principle & & & \\
\hline Principle 1: Establish clear roles and responsibilities & -0.009 & -0.764 & 0.447 \\
Principle 2: Strengthen composition & -0.231 & -4.137 & $0.000^{* * *}$ \\
Principle 3: Reinforce independence & 0.520 & 2.784 & $0.006^{* * *}$ \\
\hline$R^{2}$ & 0.152 & & \\
F-statistic & 6.700 & & \\
Significance & 0.000 & & \\
\hline Note ${ }^{* * * *}:$ Significance at the 1\% level & &
\end{tabular}

Note. $^{* * *}$ : Significance at the $1 \%$ level.

The results are interpreted as SMEs with the adoption of MCCG (2012) Principle 2 did not experience an increase in sales. Other studies by Agrawal and Knoeber (1996), De Andres, Azofra, and Lopez (2005), and Giovannini (2010) also found a negative relationship between corporate board and firm performance. This negative relationship may be due to that the benefits of more detailed and independent monitoring by a nominating committee seem to be outweighed by the difficulties in communication and coordination with the non-executive directors. However, the result for MCCG (2012) Principle 3 fully supports the notion that firm performance is significantly positively associated with this practice. This result is consistent with the perspective of both theories: Agency theory argues that independent directors monitor and control insiders; while stewardship theory emphasizes that independent directors provide valuable outside counsel and advice to firms. This result is consistent with the findings by McKnight and Mira (2003), Anderson and Reeb (2004), and Arosa et al. (2010).

\section{Conclusion}

This paper investigated the extent to which Malaysian SMEs adopted CG principles and their effects on firm performance. The results showed that $32 \%$ of the respondents said that the primary reason why they have their own business is to have control over their own working life. This finding appears to confirm the financing theory that SMEs owners have other goals than profitability. The results also showed that $30 \%$ of SMEs perceived the most important role of the board to be risk management. Hence, these boards have a greater control over financial risks that may lead to better financial performance. In addition, 81\% of the respondents' board consisted of internal board members only. These enterprises need to see the important role of external board members as a source of advice providers and experts to them. For policies relating to clear roles and responsibilities of board, only $28 \%$ of the respondents established clear functions reserved for the board and 
those delegated to management; substantial respondents did not draw up policies related to reinforcing board independence (between $75 \%$ and $79 \%$ ) and to strengthening board composition (46\%). Besides, $68 \%$ of the respondents have the position of chairman and CEO held by the same individuals and $81 \%$ of the chairman is an executive member of the board. These findings suggest that SMEs cannot see the importance of strengthening board and having independent board members. This may result in lower standards of governance among SMEs, which may adversely affect the competitiveness, potential growth, and innovation of SMEs. The regression analysis also suggests that SMEs with board independence performed better in terms of sales. Hence, SMEs need to appreciate networking advantages, competency, and strategic knowledge that the right board can offer. The government agencies in Malaysia need to take active measures to encourage SMEs to strengthen their board governance, because SMEs are the important economic powers for stimulating national economic growth. This paper contributes to the empirical literatures on the adoption of CG principles and its effect on sales performance among SMEs in emerging markets, as most of the past theoretical and empirical studies focused mainly on listed companies in developed markets.

Limitation of this study relates to a relative small sample size of 113 SMEs, where sampled SMEs did not place high priority on practicing governance principles. This may due to a lack of awareness of benefits of practicing CG principles among SMEs. In addition, governance compliance is voluntary in Malaysia, but firms are required to disclose to what they complied the codes and justify why they departed from such best practices.

\section{References}

Abor, J., \& Adjasi, C. K. D. (2007). Corporate governance and the small and medium enterprises sector: Theory and implications. Corporate Governance: The International Journal of Business in Society, 7(2), 111-122.

Agrawal, A., \& Knoeber, C. R. (1996). Firm performance and mechanisms to control agency problems between managers and shareholders. Journal of Financial and Quantitative Analysis, 31(3), 377-397.

Anderson, R. C., \& Reeb, D. M. (2004). Board composition: Balancing family influence in S\&P 500 firms. Administrative Science Quarterly, 49(2), 209-237.

Arosa, B., Iturralde, T., \& Maseda, A. (2010). Outsiders on the board of directors and firm performance: Evidence from Spanish non-listed family firms. Journal of Family Business Strategy, 1(4), 236-245.

Bennett, R. J., \& Robson, P. J. A. (2004). The role of boards of directors in small and medium-sized firms. Journal of Small Business and Enterprise Development, 11(1), 95-113.

Brunninge, O., \& Nordqvist, M. (2004). Ownership structure, board composition, and entrepreneurship: Evidence from family firms and venture-capital-backed firms. International Journal of Entrepreneurial Behavior and Research, 10(1/2), 85-105.

Brunninge, O., Nordqvist, M., \& Wiklund, J. (2007). Corporate governance and strategic change in SMEs: The effects of ownership, board composition, and top management teams. Small Business Economics, 29(3), 295-308.

De Andres, P., Azofra, V., \& Lopez, F. (2005). Corporate boards in OECD countries: Size, composition, functioning, and effectiveness. Corporate Governance: An International Review, 13(2), 197-210.

Eisenberg, T., Sundgren, S., \& Wells, M. T. (1998). Larger board size and decreasing firm value in small firms. Journal of Financial Economics, 48(1), 35-54.

Georgiou, A. K. (2010). Corporate governance and its effect on the performance on family and non-family companies listed on the Cyprus Stock Exchange (DProf thesis, Middlesex University). Retrieved from http://eprints.mdx.ac.uk/7219/

Giovannini, R. (2010). Corporate governance, family ownership, and performance. Journal of Management and Governance, 14(2), 145-166.

Htay, S. N. N., \& Salman, S. A. (2013). Corporate governance: A case study of SMEs in Malaysia. Middle-East Journal of Scientific Research, 18(2), 243-252.

Jasani, N. K. (2002). Malaysia's family businesses: The family and the business international survey report. Shamsir Jasani Grant Thorton and Malaysian Institute of Management, pp. 1-8. 
Jensen, M. C. (1993). The modern industrial revolution, exit, and the failure of internal control systems. The Journal of Finance, 48(3), 831-880.

Johannisson, B., \& Huse, M. (2000). Recruiting outside board members in the small family business: An ideological challenge. Entrepreneurship and Regional Development: An International Journal, 12(4), 353-378.

Latini, E. (2011). The development of corporate governance practices in Brazilian small and medium enterprises: Measuring effectiveness of private equity and venture capital fund managers. Paper presented at the Iberoamerican Congress of Management in Lima-Peru, pp. 1-11.

McKinsey \& Company. (2009). Management matters in Northern Ireland and Republic of Ireland. Dublin: McKinsey \& Company.

McKnight, P. J., \& Mira, S. (2003). Corporate governance mechanisms, agency costs, and firm performance in UK firms. Retrieved from http://ssrn.com/abstract $=460300$

Neville, M. (2011). The role of boards in small and medium sized firms. Corporate Governance: The International Journal of Business in Society, 11(5), 527-540.

Neville, M., \& Nykredit. (2008). Ejerlederanalysen 2008. Copenhagen: Nykredit.

Neville, M., \& Nykredit. (2010). Ejerlederanalysen 2010. Copenhagen: Nykredit.

Securities Commission Malaysia. (2012). Malaysia Code on Corporate Governance (MCCG). Kuala Lumpur.

SME Corporation Malaysia. (2013). Guideline for new SME definition. Kuala Lumpur.

Storey, D. J. (1994). Understanding the small business sector. London: Routledge.

Thomas, J., Coleman, M., \& Howieson, B. (2007). Perceptions about boards in SME sized family businesses. Electronic Journal of Family Business Studies, 1(2), 97-117.

Voordeckers, W., Van Gils, A., \& Van den Heuvel, J. (2007). Board composition in small and medium-sized family firms. Journal of Small Business Management, 45(1), 137-156. 